\title{
Effects of a Diet Supplemented with Japanese Grape (Hovenia dulcis) Seed Oil on the Omega-3 and Nutritional Lipid Quality in Nile Tilapia (Oreochromis niloticus)
}

\author{
Marina Oliveira, ${ }^{a}$ Ricardo P. Ribeiro, ${ }^{b}$ Michele C. da Silva, ${ }^{a}$ Paula F. Montanher, ${ }^{c}$ \\ Fabiana Carbonera, ${ }^{a}$ Jesuí V. Visentainer ${ }^{*, a}$ and Liane Maldaner ${ }^{a}$ \\ ${ }^{a}$ Departamento de Química and ${ }^{b}$ Departamento de Zootecnia, Universidade Estadual de Maringá (UEM), \\ Av. Colombo, 5790, 87020-900 Maringá-PR, Brazil \\ 'Departamento de Química, Universidade Tecnológica Federal do Paraná (UTFPR), \\ Rua Boa Esperança, km 04, 85660-000 Dois Vizinhos-PR, Brazil
}

\begin{abstract}
In this study, the fatty acid (FA) composition of the Japanese grape (Hovenia dulcis) seed oil (JGSO) was firstly evaluated. It was found that the seed oil is rich in alpha-linolenic acid (LNA), containing approximately $425 \mathrm{mg} \mathrm{LNA} \mathrm{g}^{-1}$ of total lipids. A fish diet supplemented with JGSO was prepared and supplied to Nile tilapia to investigate the FA composition of the fillets. For this, Nile tilapia were submitted to two feeding treatments: a control diet with $4.2 \%$ of soybean oil, and a diet supplemented with $4.2 \%$ of JGSO. The LNA, eicosapentaenoic acid (EPA), and docosahexaenoic acid (DHA) values increased significantly (406, 153 and 126\%, respectively) with JGSO in the diet and with an increase in feeding time, while the nutritional quality indexes, n- $6 / n-3$ ratio and index of thrombogenicity, decreased 2.8 and 1.4 times, respectively. Thus, the replacement JGSO in the diet raised the nutritional lipid quality in Nile tilapia.
\end{abstract}

Keywords: fatty acids, omega-3, Oreochromis niloticus, supplementation, LNA

\section{Introduction}

Omega-3 polyunsaturated fatty acids ( $n-3$ PUFA), especially alpha-linolenic acid (LNA, 18:3n-3), eicosapentaenoic acid (EPA, 20:5n-3), and docosahexaenoic acid (DHA, 22:6n-3), have been extensively studied and said to be beneficial to human health. ${ }^{1-3}$

A high ratio of dietary n-6/n-3 (omega-6/omega-3) has been reported around the world, reaching ratios between 15:1 and 20:1, while the recommended value is between $2: 1$ and $1: 1 .^{4}$ This imbalance in the $n-6 / n-3$ ratios is the result of an excess intake of omega- 6 polyunsaturated fatty acids (n-6 PUFAs) from corn, soybean, and sunflower oils. ${ }^{5}$ Furthermore, a high intake of saturated fatty acids (SFA) such as myristic acid (14:0), palmitic acid (16:0), and stearic acid (18:0), may contribute to an increase in the indexes of atherogenicity (IA) and thrombogenicity (IT) ${ }^{6}$ and to a reduction in the hypocholesterolemic/hypercholesterolemic fatty acid ratio $(\mathrm{HH}){ }^{7}$

Around the world, flaxseed, perilla, and chia are known sources of LNA, ${ }^{8-10}$ while fish and microalgae

*e-mail: jesuiv@gmail.com oils rank among the most important sources of EPA and DHA. ${ }^{11,12}$ The Japanese grape is originally from Japan, but has quickly expanded to other countries, such as India, Paraguay, Argentina, and Brazil, due to its easy adaptation to the soil and resistance to cold..$^{13}$ The Japanese grape are deciduous trees, growing to 10 to $15 \mathrm{~m}$ and reaching 20 to $40 \mathrm{~cm}$ in diameter of the trunk, commonly used for ornamental and reforestation purposes, and the wood for production of energy, paper and cellulose. The fruit is a small dry capsule from 6 to $7 \mathrm{~mm}$ in diameter containing 2 to 4 seeds, attached to a peduncle, which becomes thickened and fleshy when mature, which is also sweet and pleasant-tasting. The seeds are brown with a circular shape from 4 to $8 \mathrm{~mm}$ in diameter. ${ }^{14}$ The peduncles (pseudofruits) can be consumed in natura or in dehydrated form and are also used for alcoholic fermentation, to produce wine or vinegar. ${ }^{15,16}$ According to Bampi et al. ${ }^{13}$ the peduncles are rich in sugars and have a high content of dietary fiber. In addition, the peduncles are known to be a rich source of antioxidant compounds ${ }^{17-20}$ as well as exhibit pharmacological activities, e.g. improve the alcoholic hepatic steatosis and inflammation via regulation of lipid and inflammation metabolism ${ }^{21}$ and have preventive effects 
against cancer, diabetes and obesity. ${ }^{22}$ However, as far as we know, food applications and the fatty acid composition of the seeds were poorly studied, with a single work recently published. ${ }^{20}$ According to Rydlewski et al. ${ }^{20}$ the seeds are a rich source of PUFAs, and 53\% of the total lipids (TL) correspond to LNA. Based on that, the seeds of the Japanese grape are also a potential new source of n-3 PUFAs.

A popular, simple and easy way to improve the intake of n-3 PUFA is to supplement a diet with fish meat. However, traditional farm-raised freshwater fish, such as pintado (Pseudoplatystoma corruscans), dourado (Salminus maxillosus), and Nile tilapia (Oreochromis niloticus), have a low content of n-3 PUFAs, ${ }^{23}$ since the diet of these freshwater fish is based on lipid sources as soybean, a vegetable oil rich in n-6 PUFAs. ${ }^{23,24}$

Nowadays, several strategies to increase the levels of n-3 PUFAs in different types of food have been applied and evaluated, such as the n-3 PUFA-enrichment of poultry meat with algal biomass, ${ }^{25}$ baked goods with flaxseed flour, ${ }^{26}$ infant formula with marine oils, ${ }^{27}$ and chicken eggs with oilseeds and fish oils. ${ }^{28,29}$ Additionally, recently published studies involving Nile tilapia fed a diet supplemented with different seed oils showed an expressive increase of n-3 PUFAs in their fillets and a decrease in the n-6/n-3 ratio. ${ }^{30,31}$

In the present study, we evaluated the incorporation of LNA, the effect on EPA and DHA levels and lipid nutritional quality indexes in the fillets of Nile tilapia fed a diet supplemented with Japanese grape seed oil (JGSO).

\section{Experimental}

\section{Materials and methods}

\section{Feed preparation}

About $10 \mathrm{~kg}$ of Japanese grape fruit was harvested in the Southern Brazil, 23 33' 03" S, 51 27 ' 39" W, in the end of summer (April), period in which the fruit is ripe. The seeds were separated manually from the pulp immediately after the harvest and the seeds $(1.5 \mathrm{~kg})$ were stored under vacuum at freezer in $-18{ }^{\circ} \mathrm{C}$. Posteriorly, the seeds $(50 \mathrm{~g})$ were triturated, and placed under agitation with $100 \mathrm{~mL}$ of hexane for $6 \mathrm{~h}$ for total lipid extraction. The solvent was separated in a rotary evaporator (Fisatom $\AA$ - 801) and the crude oil (total lipid) was determined gravimetrically, and freeze-stored at $-18{ }^{\circ} \mathrm{C}$ in the dark.

The fish diets were prepared according to the fish nutritional requirements. ${ }^{32}$ The ingredients used for the diets are listed in Table 1. For the diet preparations, all of the ingredients were first ground and sieved and then homogenized and pelletized. The supplemented diet was prepared by adding JGSO as a lipid source, whereas the control diet was prepared with soybean oil (SO), which is normally used in commercial feeds. The control diet was prepared with $4.2 \%$ of SO and named treatment I (TI), and the supplemented diet was prepared with $4.2 \%$ of JGSO and named treatment II (TII).

Table 1. Composition of prepared diets

\begin{tabular}{|c|c|c|}
\hline Ingredient & Treatment $\mathrm{I}^{\mathrm{a}} / \%$ & Treatment II $^{\mathrm{b}} / \%$ \\
\hline Soybean bran & 53.65 & 53.65 \\
\hline Corn bran/maize & 21.18 & 21.18 \\
\hline Wheat bran/germ & 8.62 & 8.62 \\
\hline Brewers rice & 7.66 & 7.66 \\
\hline Bicalcium phosphate & 2.87 & 2.87 \\
\hline Salt & 0.48 & 0.48 \\
\hline Calcium propionate & 0.10 & 0.10 \\
\hline Vitamin C (mono) & 0.10 & 0.10 \\
\hline Choline chloride & 0.10 & 0.10 \\
\hline Antioxidant & 0.04 & 0.04 \\
\hline DL-Methionine & 0.14 & 0.14 \\
\hline L-Lysine & 0.19 & 0.19 \\
\hline L-Threonine & 0.14 & 0.14 \\
\hline L-Tryptophan & 0.05 & 0.05 \\
\hline Premix $^{c}$ & 0.48 & 0.48 \\
\hline Soybean oil & 4.20 & - \\
\hline Japanese grape seed oil & - & 4.20 \\
\hline \multicolumn{3}{|l|}{ Proximal composition } \\
\hline Moisture & $5.02^{\mathrm{A}} \pm 0.09$ & $6.19^{\mathrm{B}} \pm 0.09$ \\
\hline Ash & $6.79^{\mathrm{A}} \pm 0.18$ & $7.00^{\mathrm{A}} \pm 0.02$ \\
\hline Crude protein & $28.42^{\mathrm{A}} \pm 0.87$ & $27.62^{\mathrm{A}} \pm 0.60$ \\
\hline Total lipids & $10.37^{\mathrm{A}} \pm 0.98$ & $10.43^{\mathrm{A}} \pm 0.94$ \\
\hline
\end{tabular}

Data provided by Aquaculture Laboratory, Department of Zootechnics of the State University of Maringá. Results of proximal composition are expressed as mean $\pm \mathrm{SD}$ of three replicates. Values with different capital letters in the same line are significantly different $(p<0.05)$ by

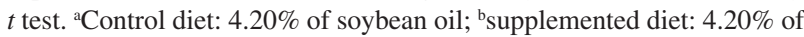
Japanese grape seed oil; ' $m$ mineral and vitamin supplement.

\section{Sampling}

This study was carried out in the Fish Experimental Station of the State University of Maringá, located in Maringá City, Paraná State, Brazil, $23^{\circ} 31^{\prime} 7.29^{\prime}$ S, $52^{\circ} 2^{\prime} 20.81^{\prime \prime} \mathrm{W}$. Twenty-four Nile tilapia with an initial individual mean weight of $101.73 \pm 0.31 \mathrm{~g}$ and length of $14.16 \pm 0.09 \mathrm{~cm}$ were randomly distributed in two tanks with capacity of $250 \mathrm{~L}$, equipped with aerators and water renovation and circulation, and submitted to feeding treatments. Prior to feeding the fish with the supplemented diet, all fish were fed with the control diet (TI) for 
adaptation for seven days. After that, each tank received its respective treatment for 30 days. During this period, the fish were fed four times a day: twice in the morning, once at the beginning of the afternoon, and once at the beginning of the night. Nile tilapia were collected (three fish per treatment) at days 0 (after adaptation time), 15, and 30 of each treatment, desensitized with a xylocaine overdose $\left(10 \mathrm{~g} \mathrm{~L}^{-1}\right)$, and disemboweled, washed, filleted, vacuum packed in polyethylene packs bags, and freezestored at $-18^{\circ} \mathrm{C}$ to avoid lipid oxidation and degradation of the PUFA until the analysis. For the analysis, the fillets of each treatment were homogenized and then analyzed in triplicate. This procedure was approved by the Ethics Committee on Animal Use in Trials at the State University of Maringá, protocol No. 012/2014, opinion No. 037/2014.

\section{Proximal composition of diets}

The moisture, ash, and crude protein in the prepared diets were determined according to $\mathrm{AOAC},{ }^{33}$ and total lipids (TL) were extracted by the method of Bligh and Dyer. ${ }^{34}$

\section{Lipid extraction method}

Total lipids (TL) of the prepared diets and fish fillets were extracted by the method of Bligh and Dyer. ${ }^{34}$ The fish fillets $(15 \mathrm{~g})$ were transferred to a beaker with a $250 \mathrm{~mL}$ capacity, while the prepared diets $(3 \mathrm{~g})$ were transferred to a beaker with a $250 \mathrm{~mL}$ capacity containing $12.0 \mathrm{~mL}$ of distilled water. Then, $45.0 \mathrm{~mL}$ of a solution of chloroform/methanol $(1: 2 \mathrm{v} / \mathrm{v})$ was added under vigorous stirring for $5 \mathrm{~min}$. After, $15.0 \mathrm{~mL}$ of chloroform was added to the mixture, which was stirred for $2 \mathrm{~min}$, followed by the addition of $15.0 \mathrm{~mL}$ of distilled water and stirring for an additional $5 \mathrm{~min}$. The mixture was filtered, separated in a $250 \mathrm{~mL}$ funnel (for $12 \mathrm{~h}$ ) and then the lower phase was evaporated at $40{ }^{\circ} \mathrm{C}$ using a rotary evaporator (Fisatom ${ }^{\circledR}$ - 801). The total lipids were determined by gravimetric analysis, and the oil was collected and stored at $-18{ }^{\circ} \mathrm{C}$ in the dark for further analysis of the fatty acids composition.

\section{Fatty acid analysis}

Transesterification and esterification of the total lipids from different samples (JGSO, SO, diets, and fish fillets) were carried out according to the methods of Hartman and Lago, ${ }^{35}$ and Maia and Rodriguez-Amaya. ${ }^{36}$ Fatty acid methyl esters (FAME) were determined by gas chromatography (GC), using a routine analysis method previously developed in our laboratory. ${ }^{37-41}$ GC analysis was carried out using a Thermo ${ }^{\mathrm{TM}}$ model TRACE ultra 3300 fitted with a flame ionization detector (FID) and a fused-silica CP-7420 (Select ${ }^{\mathrm{TM}}$ FAME) capillary column $(100 \mathrm{~m} \times 0.25 \mathrm{~mm}$ i.d. $\times 0.25 \mu \mathrm{m}$ of cianopropilpolisiloxane). The operation parameters were as follows: gas flow rates were $1.2 \mathrm{~mL} \mathrm{~min}^{-1}$ for the hydrogen as carrier gas, $30 \mathrm{~mL} \mathrm{~min}^{-1}$ for the nitrogen as a make-up gas, and 35 and $350 \mathrm{~mL} \mathrm{~min}^{-1}$ for the hydrogen and synthetic air, respectively, used for the flame of the detector. The sample, $2 \mu \mathrm{L}$, was injected, at a splitting-rate of 1:80. The temperature of the injector and detector was 230 and $240{ }^{\circ} \mathrm{C}$, respectively. The column temperature remained at $165^{\circ} \mathrm{C}$ for $7 \mathrm{~min}$, following a heating ramp for $4{ }^{\circ} \mathrm{C} \mathrm{min}{ }^{-1}$ up to $185^{\circ} \mathrm{C}$, remaining at such for $4.67 \mathrm{~min}$. After this, a new heating ramp raised the temperature to $235^{\circ} \mathrm{C}$ at a rate of $6^{\circ} \mathrm{C} \mathrm{min}^{-1}$, maintained for $5 \mathrm{~min}$, totaling 30.00 min of analysis. The retention time and the areas of the peaks of FAME were determined by ChromQuest ${ }^{\mathrm{TM}}$ 5.0 software. The identification of FAMEs was performed by comparing the retention times of the samples with those of standard methyl esters from Sigma (St. Louis, MO, USA). Quantification of fatty acids (FAs) (in mg of FA g ${ }^{-1}$ of TL) was performed according to Visentainer, ${ }^{42}$ using the tricosanoic acid methyl ester (23:0) from Sigma (St. Louis, MO, USA) as an internal standard.

\section{Lipid nutritional quality indexes}

The data from fatty acid composition analysis were used to determine the nutritional profile of the lipid fraction. Nutritional quality was assessed by three indexes: index of atherogenicity (IA), index of thrombogenicity (IT) and hypocholesterolemic/hypercholesterolemic fatty acid ratio $(\mathrm{HH})$. The index of atherogenicity (IA) indicates the relationship between the sum of the main saturated fatty acids and that of the main classes of unsaturated, the former being considered pro-atherogenic and the latter anti-atherogenic..$^{43}$ Equation 1 was applied to calculate IA, where MUFA indicates monounsaturated fatty acids.

$\mathrm{IA}=\frac{[12: 0+(4 \times 14: 0)+16: 0]}{(\text { MUFA }+\mathrm{n}-6+\mathrm{n}-3)}$

The index of thrombogenicity (IT) is defined as the relationship between the pro-thrombogenetic (saturated) and the anti-thrombogenetic fatty acids (MUFAs, $n-6$ and n-3 fatty acids). ${ }^{43}$ Equation 2 was applied to calculate IT:

$\mathrm{IT}=\frac{(14: 0+16: 0+18: 0)}{[(0.5 \times \text { MUFA })+(0.5 \times \mathrm{n}-6)+(3 \times \mathrm{n}-3)+(\mathrm{n}-3 / \mathrm{n}-6)]}$

The hypocholesterolemic/hypercholesterolemic fatty acid ratio is related to cholesterol metabolism and was calculated according to equation $3:{ }^{7}$ 
$\mathrm{HH}=\frac{(18: 1 \mathrm{n}-9+18: 2 \mathrm{n}-6+18: 3 \mathrm{n}-3+20: 4 \mathrm{n}-6+20: 5 \mathrm{n}-3+22: 5 \mathrm{n}-3+22: 6 \mathrm{n}-3)}{(14: 0+16: 0)}$

\section{Statistical analysis}

All results were submitted to one-way analysis of variance (ANOVA) using Statistica ${ }^{\mathrm{TM}} 7.0$ software, with $5 \%$ significance level $(p<0.05)$, and are presented as mean \pm standard deviation (SD). The fatty acid and proximal composition of the prepared diets were compared by $t$ test and growth, weight gain and total lipids, the fatty acid composition of Nile tilapia fillets and lipid nutritional quality indexes for different times of experimental treatments were compared by Tukey's test using Statistica ${ }^{\text {TM }} 7.0$ software. Means with different letters in the same line are significantly different $(p<0.05)$. Principal component analysis (PCA) was performed by MatLab $^{\text {TM }}$ software, version R2007b. PCA is a statistical procedure that allows the extraction of the maximum information from a data set, reducing its dimensionality, but preserving and highlighting all important and relevant information using the principal components.

\section{Results and Discussion}

\section{Proximal composition - prepared diets}

Proximal composition analysis is a crucial parameter to avoid disordered variables in an experiment comparing prepared diets. Analyzing the proximal composition results (Table 1), it is possible to observe that the diets were isocaloric and isoproteic, since no significant differences in the values of crude protein and total lipids were observed, being appropriate to use in the experiments.

Fatty acid composition - extracted oil and experimental feeds

The first experiments were carried out aiming at the determination of the fatty acid composition of Japanese grape seed oil (JGSO) and soybean oil (SO) (Table 2), i.e., the oils used for the preparation of the diets, with special attention to the LNA (18:3n-3) contents. It can be observed that in both, linoleic acid (LA, 18:2n-6) and LNA were found but in significantly different amounts. JGSO presented $425.20 \mathrm{mg} \mathrm{g}^{-1}$ of LNA in TL, which is nine times higher than that of $\mathrm{SO}$, and similar to the LNA content in golden flaxseed (483.49 $\mathrm{mg} \mathrm{g}^{-1}$ of TL) and chia oil (544.85 $\mathrm{mg} \mathrm{g}^{-1}$ of TL). ${ }^{44}$ The SO presented $515.69 \mathrm{mg} \mathrm{g}^{-1}$ of LA in TL, which is 2.5 times higher than that of JGSO. These amounts of LNA and LA yield a n-6/n-3 ratio of 0.49 for JGSO that is 23 times lower than that of SO.

The LNA content in the JGSO was high enough for the JGSO to be considered an excellent source of omega-3. According to ANVISA, ${ }^{45}$ foods with more than $0.6 \mathrm{~g}$ of LNA per $100 \mathrm{~g}$ of food are considered rich in omega-3. Japanese grape seed consists of $9 \%$ oil, resulting in a value of $3.83 \mathrm{~g}$ of LNA per $100 \mathrm{~g}$ of seed. In addition to the rich composition in PUFAs, specially LNA, the JGSO also presents low levels of SFAs (98.79 $\mathrm{mg} \mathrm{g}^{-1}$ of LT) similar to golden flaxseed (123.69 $\mathrm{mg} \mathrm{g}^{-1}$ of LT) and chia oil (83.55 $\mathrm{mg} \mathrm{g}^{-1}$ of LT). ${ }^{44} \mathrm{~A}$ dietary high intake of SFAs is associated with an increase of coronary heart diseases

Table 2. Fatty acid (FA) composition of soybean oil (SO), Japanese grape seed oil (JGSO) and supplemented diets for the treatments

\begin{tabular}{|c|c|c|c|c|}
\hline \multirow[b]{2}{*}{ Fatty acid } & \multicolumn{4}{|c|}{ Fatty acid composition / (mg g ${ }^{-1}$ of total lipids) } \\
\hline & Soybean oil (SO) & $\begin{array}{c}\text { Japanese grape seed oil } \\
\text { (JGSO) }\end{array}$ & Treatment I ${ }^{\mathrm{a}}$ & Treatment $\mathrm{II}^{\mathrm{b}}$ \\
\hline $16: 0$ & $119.09 \pm 3.08$ & $60.79 \pm 1.21$ & $98.22^{\mathrm{A}} \pm 5.35$ & $96.59^{\mathrm{A}} \pm 2.10$ \\
\hline 18:0 & $43.67 \pm 2.39$ & $37.99 \pm 0.87$ & $24.83^{\mathrm{A}} \pm 0.97$ & $31.11^{\mathrm{B}} \pm 1.18$ \\
\hline $18: 1 \mathrm{n}-9$ & $250.36 \pm 5.48$ & $190.90 \pm 1.59$ & $152.24^{\mathrm{A}} \pm 8.25$ & $168.13^{\mathrm{A}} \pm 5.64$ \\
\hline $18: 1 \mathrm{n}-7$ & $9.89 \pm 0.91$ & $13.92 \pm 0.15$ & $6.60^{\AA} \pm 0.62$ & $9.58^{\mathrm{B}} \pm 0.12$ \\
\hline $18: 2 n-6(L A)$ & $515.69 \pm 6.71$ & $207.86 \pm 1.18$ & $342.23^{\mathrm{A}} \pm 19.48$ & $254.58^{\mathrm{B}} \pm 9.64$ \\
\hline $18: 3 n-3$ (LNA) & $45.56 \pm 1.64$ & $425.20 \pm 3.02$ & $35.02^{\mathrm{A}} \pm 2.03$ & $183.11^{\mathrm{B}} \pm 7.13$ \\
\hline PUFA $^{c}$ & $561.25 \pm 8.31$ & $633.07 \pm 2.39$ & $377.25^{\mathrm{A}} \pm 21.51$ & $437.69^{\mathrm{B}} \pm 16.77$ \\
\hline MUFA $^{\mathrm{d}}$ & $260.25 \pm 4.68$ & $204.82 \pm 1.03$ & $158.84^{\mathrm{A}} \pm 8.85$ & $177.71^{\mathrm{B}} \pm 5.76$ \\
\hline $\mathrm{SFA}^{\mathrm{e}}$ & $162.76 \pm 2.17$ & $98.79 \pm 0.97$ & $123.05^{\mathrm{A}} \pm 6.32$ & $127.70^{\mathrm{A}} \pm 3.19$ \\
\hline$n-6 / n-3$ & $11.32 \pm 0.03$ & $0.49 \pm 0.03$ & $9.77^{\mathrm{A}} \pm 0.04$ & $1.39^{\mathrm{B}} \pm 0.01$ \\
\hline
\end{tabular}

Results expressed as mean \pm SD of three replicates. Values with different capital letters in the same line are significantly different $(p<0.05)$ by $t$ test. ${ }^{a} \mathrm{Control}$ diet: $4.20 \%$ of soybean oil; ${ }^{b}$ supplemented diet: $4.20 \%$ of Japanese grape seed oil; ' ${ }^{c}$ PUFA: total of polyunsaturated FA; ${ }^{\mathrm{d} M U F A}$ : total of monounsaturated FA; ${ }^{\text {SFA: }}$ total of saturated FA. 
and type 2 diabetes ${ }^{46,47}$ Therefore, the JGSO is a potential alternative to prepare supplemented diets, as suggested in the introduction section of this work.

The difference in the LA and LNA amounts in SO and JGSO allowed their use in the preparation of the diets and the subsequent evaluation of the incorporation of LNA in the fish fillets.

The lipid composition of the diets, control (TI) and supplemented (TII), were evaluated before the fish were fed (Table 2). Analyzing the results, the same profile in relation to the main FA identified and their quantities can be observed, as described above for the oils.

Comparing the treatments, TI, as expected, presented the highest value of LA, since SO was used as the lipid source, while TII presented the highest value of LNA, also as expected, since the JGSO was used as the lipid source. The $n-6 / n-3$ ratio decreased in the same proportion as the increase of LNA, i.e., the $n-6 / n-3$ ratio of TII was seven times lower than the $n-6 / n-3$ ratio of TI.

\section{Growth, weight gain and total lipids of Nile tilapia}

Analyzing the results of growth and weight gain (Figure 1), it is possible to observe that the fish accepted the prepared diets well, since they grew and gained weight during the feeding period. In addition, there was no mortality during this period.

It can also be noted in Figure 1 that the total lipids incorporated in the fish muscle tissues during the feeding time increased around $33 \%$ from $\mathrm{T}_{(0)}$ (initial sample) to $\mathrm{TI}_{(30)}$ and $\mathrm{TII}_{(30)}$ (samples of treatments I and II, respectively, during 30 days of feeding). However, although there was no significant difference between the TL values of the two treatments after 30 days, the Nile tilapias fed with the supplemented diet (TII) grew more and gained more weight to those fed with the control diet (TI). Arslan et al..$^{48}$ and Montanher et al. ${ }^{37}$ also reported this behavior, i.e., the fish preference for diets supplemented with LNA.

\section{Fatty acid composition - Nile tilapia fillets}

The main FAs found in the Nile tilapia fillets fed with the prepared diets are shown in Table 3. More fatty acids were found in the fish fillets compared to the oils and the prepared diets, since the fish fillets are complex samples and the fish metabolism transforms/converts some fatty acids to others. As can be observed, in addition to LA and LNA, arachidonic acid (AA), EPA, and DHA were identified, which are relevant PUFAs synthesized from LA and LNA. This synthesis occurs because freshwater fish as well as humans have enzymes able to convert LNA and LA in these other important FAs. ${ }^{49}$

Furthermore, LNA values increased significantly with the supplemented diet and with the increase in time of feeding, ranging from $8.93 \mathrm{mg} \mathrm{g}^{-1}$ of TL, when no JGSO was added to the diet, to $45.2 \mathrm{mg} \mathrm{g}^{-1}$ of TL, when $4.2 \%$ of JGSO was added. These results indicate that LNA from the JGSO was incorporated in the fish fillets.

Analyzing the values of DHA, EPA and AA determined in the Nile tilapia fillets, it is possible to note that EPA and DHA values also increased significantly (153 and $126 \%$, respectively) with the supplemented diet and with the increase in time of feeding. On the other hand, the AA values remained almost the same for all feeding times and treatments. This was expected, since LNA is the precursor of EPA and DHA, while LA is the precursor of AA. ${ }^{50}$

By the comparison of the results from TL (Figure 1) and the FA composition of the fish fillets (Table 3), it can be observed that for both treatments $\left(\mathrm{TI}_{(30)}\right.$ and $\left.\mathrm{TII}_{(30)}\right)$ the $\mathrm{TL}$ increased significantly during the feeding time. However, the fish fillets from $\operatorname{TII}_{(30)}$ incorporated significantly higher amounts of n-3 FAs, raising the nutritional lipid quality of the freshwater fish fed with the supplemented diet with JGSO.
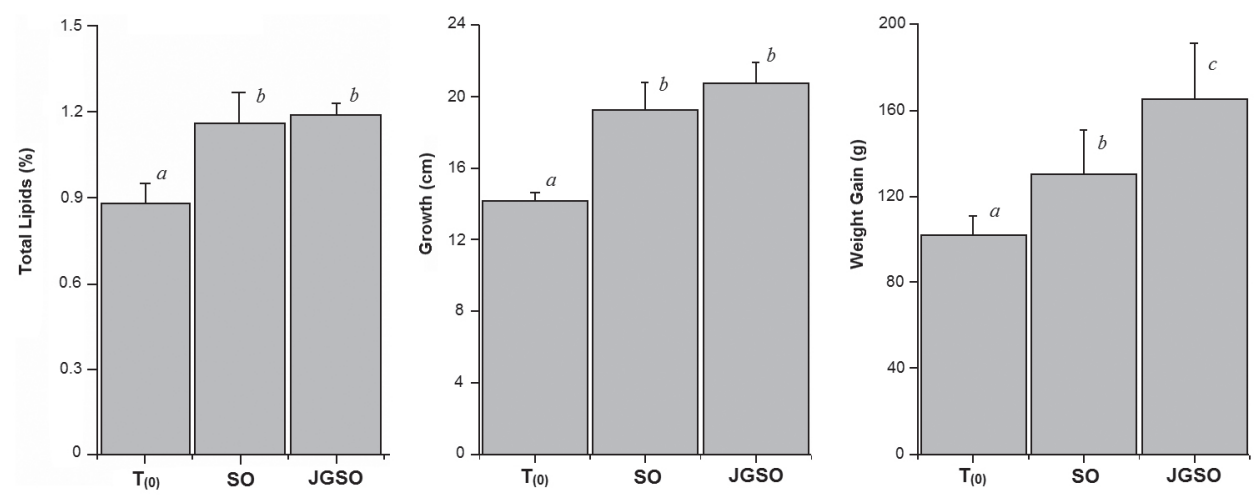

Figure 1. Total lipids, growth and weight gain after seven days of adaptation $\left(\mathrm{T}_{(0)}\right)$ and after 30 days of TI (SO) and TII (JGSO). Values with different letters in the same graphic are significantly different $(p<0.05)$ by Tukey's test. 
Table 3. Fatty acid (FA) composition of tilapia fillets after different times of experimental treatment

\begin{tabular}{|c|c|c|c|c|c|}
\hline \multirow{2}{*}{ Fatty acid } & \multirow{2}{*}{$\begin{array}{l}\mathrm{T}_{(0)} \mathrm{c} /\left(\mathrm{mg} \mathrm{g}^{-1} \text { of }\right. \\
\text { total lipids) }\end{array}$} & \multicolumn{2}{|c|}{ Treatment $\mathrm{I}^{\mathrm{a}} /\left(\mathrm{mg} \mathrm{g}^{-1}\right.$ of total lipids) } & \multicolumn{2}{|c|}{ Treatment $\mathrm{II}^{\mathrm{b}} /\left(\mathrm{mg} \mathrm{g}^{-1}\right.$ of total lipids) } \\
\hline & & $\mathrm{TI}_{(15)}{ }^{\mathrm{d}}$ & $\mathrm{TI}_{(30)}{ }^{\mathrm{d}}$ & $\mathrm{TII}_{(15)} \mathrm{e}^{\mathrm{e}}$ & $\mathrm{TII}_{(30)}{ }^{\mathrm{e}}$ \\
\hline $14: 0$ & $14.41^{\mathrm{A}} \pm 2.81$ & $13.95^{\mathrm{A}} \pm 0.84$ & $11.78^{\mathrm{A}} \pm 1.77$ & $12.99^{\mathrm{A}} \pm 0.78$ & $11.84^{\mathrm{A}} \pm 2.11$ \\
\hline $16: 0$ & $183.73^{\mathrm{A}} \pm 21.01$ & $158.38^{\mathrm{A}} \pm 6.18$ & $160.59^{\mathrm{A}} \pm 17.14$ & $164.37^{\mathrm{A}} \pm 15.13$ & $162.23^{\mathrm{A}} \pm 20.83$ \\
\hline $16: 1$ & $17.98^{\mathrm{A}} \pm 2.44$ & $22.50^{\mathrm{B}} \pm 1.65$ & $19.95^{\mathrm{AB}} \pm 1.22$ & $19.97^{\mathrm{AB}} \pm 0.60$ & $17.62^{\mathrm{A}} \pm 1.29$ \\
\hline $18: 0$ & $73.67^{\mathrm{B}} \pm 7.14$ & $55.69^{\mathrm{A}} \pm 2.13$ & $60.78^{\mathrm{A}} \pm 6.46$ & $59.88^{\mathrm{A}} \pm 6.88$ & $60.63^{\mathrm{A}} \pm 7.85$ \\
\hline $18: \ln -9 \mathrm{c}$ & $223.59^{\mathrm{A}} \pm 24.72$ & $227.31^{\mathrm{A}} \pm 16.42$ & $196.19^{\mathrm{AB}} \pm 11.32$ & $203.35^{\mathrm{AB}} \pm 8.60$ & $180.31^{\mathrm{B}} \pm 7.73$ \\
\hline $18: 2 n-6(L A)$ & $128.94^{\mathrm{B}} \pm 13.06$ & $157.73^{\mathrm{A}} \pm 10.40$ & $147.64^{\mathrm{AB}} \pm 6.98$ & $153.44^{\mathrm{A}} \pm 3.18$ & $155.69^{\mathrm{A}} \pm 0.90$ \\
\hline $18: 3 n-3$ (LNA) & $8.93^{\mathrm{A}} \pm 1.63$ & $11.40^{\mathrm{A}} \pm 2.41$ & $9.01^{\mathrm{A}} \pm 0.63$ & $34.54^{\mathrm{B}} \pm 0.92$ & $45.2^{\mathrm{C}} \pm 0.46$ \\
\hline $20: 4 n-6$ (AA) & $23.81^{\mathrm{A}} \pm 3.66$ & $26.64^{\mathrm{A}} \pm 0.56$ & $33.6^{\mathrm{B}} \pm 0.84$ & $22.69^{\mathrm{A}} \pm 0.38$ & $27.92^{\mathrm{A}} \pm 2.66$ \\
\hline $20: 5 n-3$ (EPA) & $0.68^{\mathrm{B}} \pm 0.04$ & $0.84^{\mathrm{A}} \pm 0.04$ & $0.92^{\mathrm{A}} \pm 0.02$ & $1.14^{\mathrm{C}} \pm 0.03$ & $1.72^{\mathrm{D}} \pm 0.10$ \\
\hline $22: 6 n-3$ (DHA) & $12.89^{\mathrm{B}} \pm 2.12$ & $16.13^{\mathrm{A}} \pm 0.29$ & $22.39^{\mathrm{C}} \pm 0.47$ & $19.06^{\mathrm{A}} \pm 0.42$ & $29.08^{\mathrm{D}} \pm 3.18$ \\
\hline PUFA $^{\mathrm{f}}$ & $175.25^{\mathrm{B}} \pm 16.11$ & $212.74^{\mathrm{A}} \pm 12.17$ & $213.56^{\mathrm{A}} \pm 7.91$ & $230.87^{\mathrm{A}} \pm 2.94$ & $259.61^{\mathrm{C}} \pm 6.97$ \\
\hline MUFA $^{g}$ & $241.57^{\mathrm{AB}} \pm 26.71$ & $249.81^{\mathrm{B}} \pm 18.06$ & $216.14^{\mathrm{AB}} \pm 12.47$ & $223.32^{\mathrm{AB}} \pm 9.17$ & $197.93^{\mathrm{A}} \pm 9.01$ \\
\hline $\mathrm{SFA}^{\mathrm{h}}$ & $271.81^{\mathrm{A}} \pm 30.04$ & $228.02^{\mathrm{A}} \pm 8.64$ & $233.15^{\mathrm{A}} \pm 25.28$ & $237.24^{\mathrm{A}} \pm 22.78$ & $234.70^{\mathrm{A}} \pm 30.77$ \\
\hline$\Sigma \mathrm{n}-6^{\mathrm{i}}$ & $152.75^{\mathrm{B}} \pm 14.15$ & $184.36^{\mathrm{A}} \pm 9.94$ & $181.24^{\mathrm{A}} \pm 7.11$ & $176.13^{\mathrm{A}} \pm 2.81$ & $183.61^{\mathrm{A}} \pm 3.49$ \\
\hline$\Sigma n-3^{j}$ & $22.49^{\mathrm{A}} \pm 2.02$ & $28.36^{\mathrm{AB}} \pm 2.25$ & $32.32^{\mathrm{C}} \pm 0.96$ & $54.74^{\mathrm{D}} \pm 1.13$ & $76.00^{\mathrm{E}} \pm 3.71$ \\
\hline$n-6 / n-3$ & $6.79^{\mathrm{A}} \pm 0.17$ & $6.50^{\mathrm{A}} \pm 0.17$ & $5.61^{\mathrm{D}} \pm 0.13$ & $3.22^{\mathrm{C}} \pm 0.09$ & $2.42^{\mathrm{B}} \pm 0.08$ \\
\hline
\end{tabular}

Results expressed as mean \pm SD of three replicates. Values with different capital letters in the same line are significantly different $(p<0.05)$ by Tukey's test. ${ }^{a}$ Treatment I: control diet, $4.20 \%$ of soybean oil; ${ }^{b}$ treatment II: supplemented diet, $4.20 \%$ of Japanese grape seed oil; ${ }^{\circ} \mathrm{T}_{(0)}$ : initial sample, after adaptation time; ${ }^{\mathrm{d}} \mathrm{TI}_{(15)}$ and $\mathrm{TI}_{(30)}$ : samples of treatment I during 15 and 30 days of feeding, respectively; ${ }^{\mathrm{e}} \mathrm{TII}_{(15)}$ and $\mathrm{TII}_{(30)}$ : samples of treatment $\mathrm{II}$ during 15 and

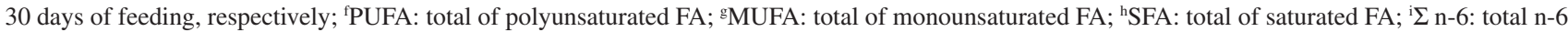
FA; ${ }^{j} \Sigma \mathrm{n}-3$ : total n-3 FA.

Moreover, the n-6/n-3 ratio decreased 2.8 times in the fish fillets, especially with the increase of LNA, as was already described for the prepared diets. The decrease of the $n-6 / n-3$ ratio for the fish fillets was not in the same proportion as that for the prepared diets due to the influence of metabolic factors, including digestibility and preferential fatty acid catabolism, which may affect the FA composition in the fish fillets. ${ }^{51-53}$ Even so, the n-6/n-3 ratio for the fish fillets from $\operatorname{TII}_{(30)}$ was significantly closer to the values suggested by Simopoulos, ${ }^{4}$ i.e., the closer the n-6/n-3 ratio to $1: 1$, the better it will be for the prevention of many diseases, such as diabetes, cancer, obesity, and cardiovascular and autoimmune diseases.

\section{Lipid nutritional quality indexes}

Table 4 shows the nutritional profile of the lipid fraction of the Nile tilapia fillets fed with the prepared diets. The indexes of atherogenicity (IA) and thrombogenicity (IT) indicate the global dietetic quality of lipids and their potential effects on the development of coronary diseases ${ }^{43}$ while the $\mathrm{HH}$ ratio considers the specific effect of fatty acids on cholesterol metabolism. ${ }^{54}$ As can be observed in Table 4, the values for IA decreased and $\mathrm{HH}$ increased, from zero time to treatment I and II in both feeding times; however, the increase and decrease do not provide significant difference between the treatments. On the other hand, a significant difference $(p<0.05)$ with a decrease was observed in IT from zero time (1.00) and treatment I (0.77) to the treatment II (0.56), at the final of supplementation (30 days), due to the higher content of total PUFAs and n-3 fatty acids in the Nile tilapia fillets as showed in Table 3. Lower values are desirable for IT indices due to the better nutritional quality of the fat, related to a decrease in risk of cardiovascular disease. The results obtained were lower than those reported for some freshwater fish, such as Nile tilapia GIFT $(0.67),{ }^{55}$ Tilapia roja (1.42), Barbado (1.18), and Jau (1.00) ${ }^{55}$ and fish from the Amazon basin, such as Colossoma macropomum (0.65), Brachyplatystoma filamentosum (0.89) and Brachyplatystoma flavicans (0.89). ${ }^{56}$

\section{Statistical analysis}

To explain the analysis of the results on a statistical basis, and to establish the corresponding correlations between the variables, the PCA method was used, as shown in Figure 2. For the PCA analysis, three PCs were used to explain $98.97 \%$ of the total variance of the data. 
Table 4. Lipid nutritional quality indexes of tilapia fillets after different times of experimental treatments

\begin{tabular}{lccccc}
\hline \multirow{2}{*}{ Index } & $\mathrm{T}_{(0)}{ }^{\mathrm{c}}$ & \multicolumn{2}{c}{ Treatment I $^{\mathrm{a}}$} & \multicolumn{2}{c}{ Treatment II $^{\mathrm{b}}$} \\
\cline { 3 - 6 } & & $\mathrm{TI}_{(15)}{ }^{\mathrm{d}}$ & $\mathrm{TI}_{(30)}{ }^{\mathrm{d}}$ & $\mathrm{TII}_{(15)}{ }^{\mathrm{e}}$ & $\mathrm{TII}_{(30)}{ }^{\mathrm{e}}$ \\
\hline IA & $0.58^{\mathrm{A}} \pm 0.06$ & $0.46^{\mathrm{A}} \pm 0.01$ & $0.48^{\mathrm{A}} \pm 0.04$ & $0.48^{\mathrm{A}} \pm 0.04$ & $0.46^{\mathrm{A}} \pm 0.06$ \\
IT & $1.00^{\mathrm{A}} \pm 0.10$ & $0.74^{\mathrm{BC}} \pm 0.03$ & $0.77^{\mathrm{B}} \pm 0.07$ & $0.65^{\mathrm{BC}} \pm 0.06$ & $0.56^{\mathrm{C}} \pm 0.09$ \\
HH & $2.02^{\mathrm{A}} \pm 0.18$ & $2.55^{\mathrm{A}} \pm 0.08$ & $2.39^{\mathrm{A}} \pm 0.19$ & $2.46^{\mathrm{A}} \pm 0.20$ & $2.56^{\mathrm{A}} \pm 0.32$ \\
\hline
\end{tabular}

Results expressed as means \pm SD. Different capital letters in the line mean significant differences $(p<0.05)$ by Tukey's test. ${ }^{a}$ Treatment I: control diet, $4.20 \%$ of soybean oil; btreatment II: supplemented diet, $4.20 \%$ of Japanese grape seed oil; ${ }^{\mathrm{c}} \mathrm{T}_{(0)}$ : initial sample, after adaptation time; ${ }^{\mathrm{d}} \mathrm{TI}_{(15)}$ and $\mathrm{TI}_{(30)}$ : ${ }^{2} \mathrm{smples} \mathrm{of}$ treatment I during 15 and 30 days of feeding, respectively; ${ }^{\mathrm{C}} \mathrm{TII}_{(15)}$ and $\mathrm{TII}_{(30)}$ : samples of treatment II during 15 and 30 days of feeding, respectively. IA: index of atherogenicity; IT: index of thrombogenicity; HH: hypocholesterolemic/hypercholesterolemic fatty acid ratio.

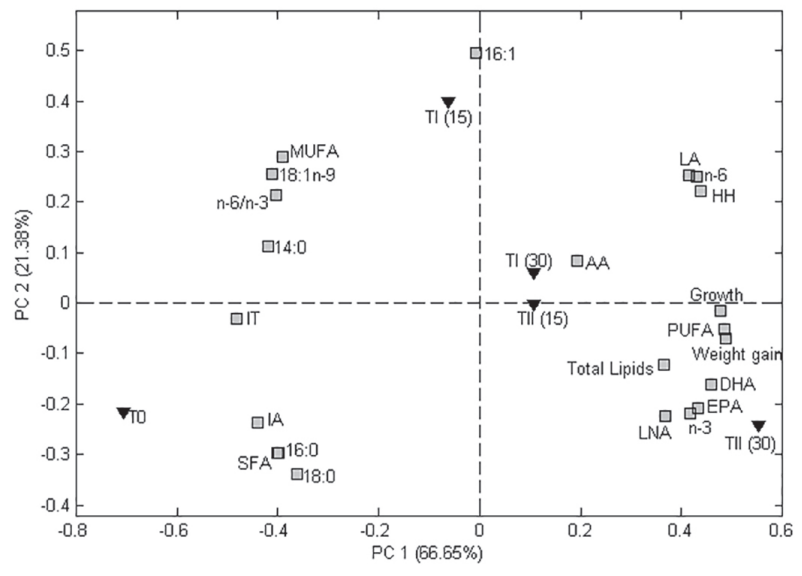

Figure 2. Biplot of PC1-PC2 for the treatments, fatty acid composition, $\mathrm{n}-6 / \mathrm{n}-3$ ratio, total lipids and lipid nutritional quality indexes in the fish fillets, and growth and weight gain of the fish.

The biplot of PC1-PC2 explains the relation between the treatments, fatty acid composition, n-6/n-3 ratio, total lipids and lipid nutritional quality indexes (IA, IT and $\mathrm{HH}$ ) in the fish fillets, and growth and weight gain of the fish.

Analyzing PC2, it is possible to observe that the data were decomposed according to the increases of LNA, EPA and DHA, generating two distinct groups: one composed of the treatments based on JGSO $\left(\mathrm{TII}_{(15)}\right.$ and $\left.\mathrm{TII}_{(30)}\right)$, which resulted in a greater amount of n-3 FAs in the fillets, and the second composed of the control treatment, which is based on $\mathrm{SO}\left(\mathrm{TI}_{(15)}\right.$ and $\left.\mathrm{TI}_{(30)}\right)$ and resulted in a smaller increase in the amount of these n-3 FAs in the fillets. In addition, the first group also includes the growth, weight gain and the TL of the fish, showing that the fish fed with the treatments based on JGSO (TII), grew more, gained more weight and incorporated significantly higher amounts of n-3 FAs to those fed with the control treatments (TI).

Analyzing PC1, it is possible to observe that the data were also decomposed in two distinct groups, the first one according to the decreases of SFAs, MUFAs, $n-6 / n-3$ ratio and IA and IT indexes and the second one according to the increases of PUFAs, growth, weight gain, TL and HH index.
These results are in agreement with the experimental data presented in Figure 1, Tables 3 and 4.

\section{Conclusions}

The study of the fatty acid composition showed that Japanese grape seed is a rich source of omega-3, being a potential alternative in preparing supplemented diets.

The prepared diets were isocaloric and isolipidic, and the fish accepted both of the diets well, but a greater growth and weight gain was observed in the fish fed the diet supplemented with JGSO.

The high content of LNA in JGSO contributed to the satisfactory replacement of SO by JGSO in the prepared diets, since increases in the levels of LNA, EPA, and DHA, as well as decreases in the $n-6 / n-3$ ratios and IT were observed in the Nile tilapia fillets.

Thus, the supplementation of fish diets with oil sources rich in LNA, such as JGSO, may be a promising alternative for an increase in the important n-3 fatty acids and raising the lipid quality of freshwater fish.

\section{Acknowledgments}

We thank Coordenação de Aperfeiçoamento de Pessoal de Nível Superior (CAPES), Conselho Nacional de Desenvolvimento Científico e Tecnológico (CNPq), and Fundação Araucária for their financial support, and Companhia de Desenvolvimento Agropecuário do Paraná (CODAPAR) for providing the fish used in this study.

\section{References}

1. Ellulu, M. S.; Khaza'ai, H.; Abed, Y.; Rahmat, A.; Ismail, P.; Ranneh, Y.; Inflammopharmacology 2015, 23, 79.

2. Fritsche, K. L.; Adv. Nutr. 2015, 6, 293S.

3. Skilton, M. R.; Pahkala, K.; Viikari, J. S. A.; Rönnemaa, T.; Simell, O.; Jula, A.; Niinikoski, H.; Celermajer, D. S.; Raitakari, O. T.; J. Pediatr. 2015, 166, 1252. 
4. Simopoulos, A. P.; Biomed. Pharmacother. 2002, 56, 365.

5. Simopoulos, A. P.; Nutrients 2013, 5, 2901.

6. Ulbricht, T. L. V.; Southgate, D. A. T.; Lancet 1991, 338, 985.

7. Santos-Silva, J.; Bessa, R. J. B.; Santos-Silva, F.; Livest. Prod. Sci. 2002, 77, 187.

8. Barceló-Coblijn, B.; Murphy, E. J.; Prog. Lipid Res. 2009, 48, 355.

9. Segura-Campos, M. R.; Ciau-Solís, N.; Rosado-Rubio, G.; Chel-Guerrero, L.; Betancur-Ancona, D.; Agric. Sci. 2014, 5, 220.

10. Goyal, A.; Sharma, V.; Sihag, M. K.; Tomar, S. K.; Arora, S.; Sabikhi, L.; Singh, A. K.; Powder Technol. 2015, 286, 527.

11. Patil, V.; Reitan, K. I.; Knutsen, G.; Mortensen, L. M.; Kallqvist, T.; Olsen, E.; Vogt, G.; Gislerod, H. R.; Curr. Top. Plant Biol. 2005, 6, 57.

12. Ryckebosch, E.; Bruneel, C.; Termote-Verhalle, R.; Goiris, K.; Muylaert, K.; Foubert, I.; Food Chem. 2014, 160, 393.

13. Bampi, M.; Bicudo, M. O. P.; Fontoura, P. S. G.; Ribani, R. H.; Cienc. Rural 2010, 40, 2361.

14. Carvalho, P. E. R.; Circular Técnica, No. 23, Ecologia, Silvicultura e Usos da Uva-do-Japão (Hovenia dulcis Thunberg), Embrapa-CNPFlorestas: Colombo, 1994. Available at https://www.infoteca.cnptia.embrapa.br/infoteca/bitstream/ doc/290745/1/circtec23.pdf, accessed in August 2017.

15. Maieves, H. A.; Ribani, R. H.; de Jesus, A. M. F.; de Godoy, R. C. B.; Comunicado Técnico, Uva-do-Japão (Hovenia dulcis) - Valor Nutricional e Aceitabilidade, Embrapa Florestas: Colombo, 2015. Available at http://www. infoteca.cnptia.embrapa.br/infoteca/bitstream/doc/1038599/1/ ComunicadoTecnico361201529032016.pdf, accessed in August 2017.

16. Fiorio, J. L.; Galvan, D.; Dalposso, P. V.; da Cunha, M. A. A.; Spinosa, W. A.; Rev. Bras. Prod. Agroind. 2015, 17, 277.

17. Hyun, T. K.; Eom, S. H.; Yu, C. Y.; Roitsch, T.; Planta Med. 2010, 76, 943.

18. Maieves, H. A.; López-Froilán, R.; Morales, P.; PérezRodríguez, M. L.; Ribani, R. H.; Cámara, M.; Sánchez-Mata, M. C.; J. Funct. Foods 2015, 18, 1117.

19. Wang, M.; Zhu, P.; Jiang, C.; Ma, L.; Zhang, Z.; Zeng, X.; Food Chem. Toxicol. 2012, 50, 2964.

20. Rydlewski, A. A.; de Morais, D. R.; Rotta, E. M.; Claus, T.; Vagula, J. M.; da Silva, M. C.; Santos-Junior, O. O.; Visentainer, J. V.; J. Food Qual. 2017, ID 8401074. DOI https://doi. org/10.1155/2017/8401074.

21. Choi, R.; Woo, M.; Ham, J. R.; Lee, M.; Biomed Pharmacother. 2017, 90, 393.

22. Park, J. S.; Kim, I. S.; Rehman, S. U.; J. Chromatogr. Sci. 2016, $54,130$.

23. Vasconi, M.; Caprino, F.; Bellagamba, F.; Busetto, M. L.; Bernardi, C.; Puzzi, C.; Moretti, V. M.; Lipids 2015, 50, 283.
24. Li, G.; Sinclair, A. J.; Li, D.; J. Agric. Food Chem. 2011, 59, 1871.

25. Al-Khalifa, H.; World's Poult. Sci. J. 2015, 71, 319.

26. Kadam, S. U.; Prabhasankar, P.; Food Res. Int. 2010, 43, 1975.

27. Uauy, R.; Hoffman, D. R.; Birch, E. E.; Birch, D. G.; Jameson, D. M.; Tyson, J.; J. Pediatr. 1994, 124, 612.

28. Coorey, R.; Novinda, A.; Williams, H.; Jayasena, V.; J. Food Sci. 2015, 80, S180.

29. Goldberg, E. M.; Gakhar, N.; Ryland, D.; Aliani, M.; Gibson, R. A.; House, J. D.; J. Food Sci. 2012, 77, S153.

30. Carbonera, F.; Montanher, P. F.; Figueiredo, I. L.; Bonafé, E. G.; Junior, O. O. S.; Sargi, S. C.; Gonçalves, R. M.; Matsushita, M.; Visentainer, J. V.; J. Am. Oil Chem. Soc. 2016, 93, 1255.

31. Bonafé, E. G.; Figueiredo, L. C.; Martins, A. F.; Monteiro, J. P.; Junior, O. O. S.; Canesin, E. A.; Maruyama, S. A.; Visentainer, J. V.; J. Sci. Food Agric. 2017, 97, 3469.

32. National Research Council (NRC), Nutrient Requirements of Fish, The National Academies Press: Washington, DC, 1993.

33. Association of Official Analytical Chemists; Official Methods of Analysis of AOAC International; Cunniff, P. A., ed.; AOAC: Arlington, 1998.

34. Bligh, E. G.; Dyer, W. J.; Can. J. Biochem. Physiol. 1959, 37, 911.

35. Hartman, L.; Lago, R. C. A.; Lab. Pract. 1973, 22, 475.

36. Maia, E. L.; Rodriguez-Amaya, D. B.; Rev. Inst. Adolfo Lutz 1993, 53, 27.

37. Montanher, P. F.; Silva, B. C.; Bonafé, E. G.; Carbonera, F.; dos Santos, H. M. C.; Figueiredo, I. L.; Maruyama, S. A.; Matsushita, M.; Visentainer, J. V.; Eur. J. Lipid Sci. Technol. 2016, 118, 698.

38. Martin, C. A.; Oliveira, C. C.; Visentaiver, J. V.; Matsushita, M.; Souza, N. E.; J. Chromatogr. A 2008, 111, 1941.

39. Lopes, A. P.; Schneider, V. V. A.; Montanher, P. F.; Figueiredo, I. L.; Santos, H. M. C.; Maruyama, S. A.; Araujo, A. M. M.; Visentainer, J. V.; J. Braz. Chem. Soc. 2015, 26, 572.

40. Schneider, V. V. A.; Carbonera, F.; Montanher, P. F.; Lopes, A. P.; Matsushita, M.; Visentainer, J. V.; J. Am. Oil Chem. Soc. 2015, 92, 693.

41. Schneider, V. V. A.; Carbonera, F.; Lopes, A. P.; Santos, O. O.; Oliveira, C. C.; Souza, N. E.; Visentainer, J. V.; J. Am. Oil Chem. Soc. 2015, 92, 225.

42. Visentainer, J. V.; Quim. Nova 2012, 35, 274.

43. Ulbricht, T. L. V.; Southgate, D. A. T.; Lancet 1991, 338, 985.

44. Sargi, S. C.; Silva, B. C.; Santos, H. M. C.; Montanher, P. F.; Boeing, J. S.; Santos-Junior, O. O.; Souza, N. E.; Visentainer, J. V.; Food Sci. Technol. (Campinas) 2013, 33, 541.

45. ANVISA, Regulamento Técnico Sobre Informação Nutricional Complementar; http://portal.anvisa.gov.br/documents/\%20 33880/2568070/rdc0054_12_11_2012.pdf/c5ac23fd-974e4f2c-9fbc-48f7e0a31864, accessed in August 2017. 
46. Zong, G.; Li, Y.; Wanders, A. J.; Alssema, M.; Zock, P. L.; Willett, W. C.; Hu, F. B.; Sun, Q.; BMJ [Br. Med. J.] 2016, 355, i5796. DOI http://dx.doi.org/10.1136/bmj.i5796.

47. de Souza, R. J.; Mente, A.; Maroleanu, A.; Cozma, A. I.; Ha, V.; Kishibe, T.; Uleryk, E.; Budylowski, P.; Schünemann, H.; Beyene, J.; Anand, S.; BMJ [Br. Med. J.] 2015, 351, h3978. DOI 10.1136/bmj.h3978.

48. Arslan, M.; Sirkecioglu, N.; Bayir, A.; Arslan, H.; Aras, M.; Turk. J. Fish. Aquat. Sci. 2012, 12, 575.

49. Henderson, R. J.; Tocher, D. R.; Prog. Lipid Res. 1987, 26, 281.

50. Kajla, P.; Sharma, A.; Sood, D. R.; J. Food Sci. Technol. 2014, 52, 1857.

51. Dizhi, X.; Liping, Y.; Ruomeng, Y.; Fang, C.; Ronghua, L.; Chaobin, Q.; Guoxing, N.; Aquaculture 2017, 479, 696.
52. Bell, J. G.; McEvoy, J.; Tocher, D. R.; McGhee, F.; Campbell, P. J.; Sargent, J. R.; J. Nutr. 2001, 131, 1535.

53. Torstensen, B. E.; Lie, O.; Froyland, L.; Lipids 2000, 35, 653.

54. Ramos-Filho, M. M.; Ramos, M. I. L.; Hiane, P. A.; Souza, E. M. T.; J. Am. Oil Chem. Soc. 2010, 87, 1461.

55. dos Santos, H. M. C.; Nishiyama, M. F.; Bonafe, E. G.; de Oliveira, C. A. L.; Matsushita, M.; Visentainer, J. V.; Ribeiro, R. P.; J. Am. Oil Chem. Soc. 2014, 91, 1939.

56. Petenuci, M. E.; Rocha, I. N. A.; de Sousa, S. C.; Schneider, V. V. A.; da Costa, L. A. M. A.; Visentainer, J. V.; J. Am. Oil Chem. Soc. 2016, 93, 1373.

Submitted: June 11, 2017

Published online: September 5, 2017 